\title{
Painting the Odalisque: Reclaiming the Hierarchies of Aesthetics by Trans-Modern Critique
}

\author{
Mohammed Baker Mohammed Al-Abbas (Ph.D) \\ The University of Jordan, Faculty of Art and Design, Department of Visual Arts
}

\begin{abstract}
This article critiqued western aesthetics, which manipulated the representations of the oriental social reality in Modern Painting. Western aesthetics created an illusionistic link between the oriental society and occidental audience when modern artists from western cultures painted the orient and exaggerated the images of its people, landscape and visual cultures. The phenomenon of painting the odalisque was one of the stereotypical imagery made on the oriental cultures. This requires a trans-modern critique as well as trans-aesthetic rethinking to translate the real oriental realities to the western audience. Furthermore, such critique illustrates a clearer picture of the oriental trans-modernity and its cultural connections. The cliche of the odalisque is the subject of this critical article while rethinking the structures of western aesthetics through post-colonial as well as multicultural critique is its purpose. This article contributes to the critical literature that investigates the oriental cultures from global and trans-aesthetic perspectives.
\end{abstract}

Keywords: Trans-Modernity, Contemporary Aesthetics, Orient, the Art of Painting.

DOI: $10.7176 / \mathrm{JTHS} / 43-06$

Publication date:September $30^{\text {th }} 2019$

\section{The Trans-Modern Critique:}

This study introduces a multicultural, trans-aesthetic and trans-modern critique that negotiates the subject of the odalisque in the modern western paintings. The philosophical context of this critique is postcolonial, and the dilemma of this study is that the western artists imagined the orient as a cliché. Their idea of the orient reflected various contrasts of politics, religions, and cultures. This study protests against the mainstream aesthetics in the orientalist painting during the modern colonialism. It is important to note that this study critiques the artistic phenomenon rather than the artists, as they indeed represented their arts from an individual, creative and imaginative perspectives reflecting personal experience.

In the context of rethinking particular biases that existed during the western modernism, the hierarchies of occidental aesthetics represented the non-European women as sexual objects. This phenomenon had been a trend during the neoclassical and romantic phases of painting in western modernity, the product of eastern sexuality found its way to the European market through the art of painting. Such a possible trend of the other's sexuality defined the boundaries of people who might be portrayed as latent political subjects with sexual manifestations, thus exposed to the gazes of the western audience (Saed, 1978). The political landscape during the rise of modernity in the 19th century was remarkably distinct from today's political landscape, into which European geography coexisted next to the Ottoman extended geography, culture, and trade. The Ottoman influence declined while the European powers started to play a greater impact on the geographies of Turkish culture (Acuna, 2013). In the context of this political and cultural turbulence between the occident and the orient, sexuality emerged into the themes of the political debates of colonialism. The iconographies of the odalisque appeared as an exotic motif in western art history, which represented eastern women voluptuously. 


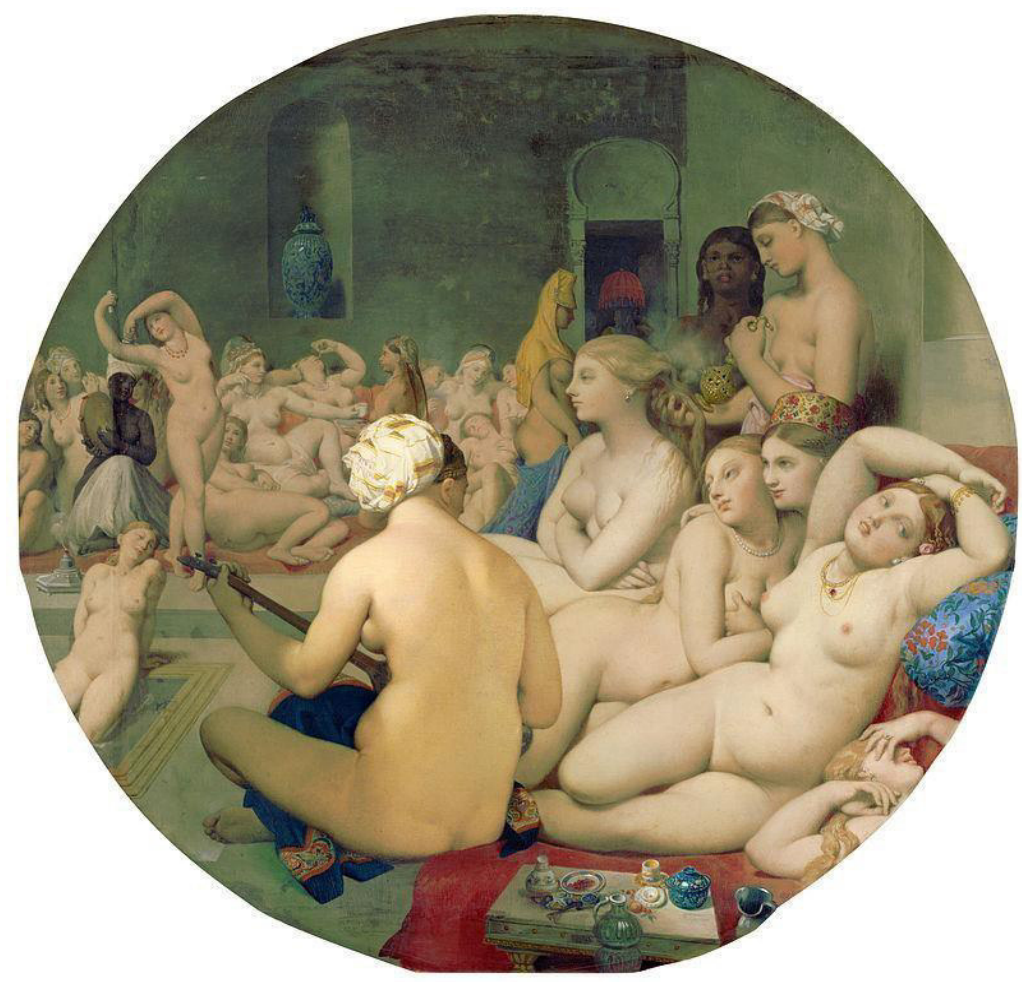

Figure 1: Ingres. Turkish Bath. 1863, oil on canvas mounted on panel, Louvre Museum, Paris.

In the context of oriental versus occidental aesthetics, finding independent characteristics needs transaesthetics to evaluate the productions of their high and popular arts that hybridized western and eastern visual cultures. As the current global culture demonstrates the social perceptions of people and distinguishes aesthetic patterns according to geographies and histories (Groat and Wang, 2013). Edward Said (1935-2003) defined Orientalism as an academic approach that appeared among the western colonial literature, to describe the nonwestern cultures and languages. Said (1978) described the conception of Orientalism as a colonial tool, which was used to rationalize the western cultural, economic, and political domination. Orientalism pretends to be an objective system of western research, which on reality established several racial and cultural stereotypes, leading into a big gap between the western theories and histories of the Orient on one side, and its social reality on the other side (Said, 1978).

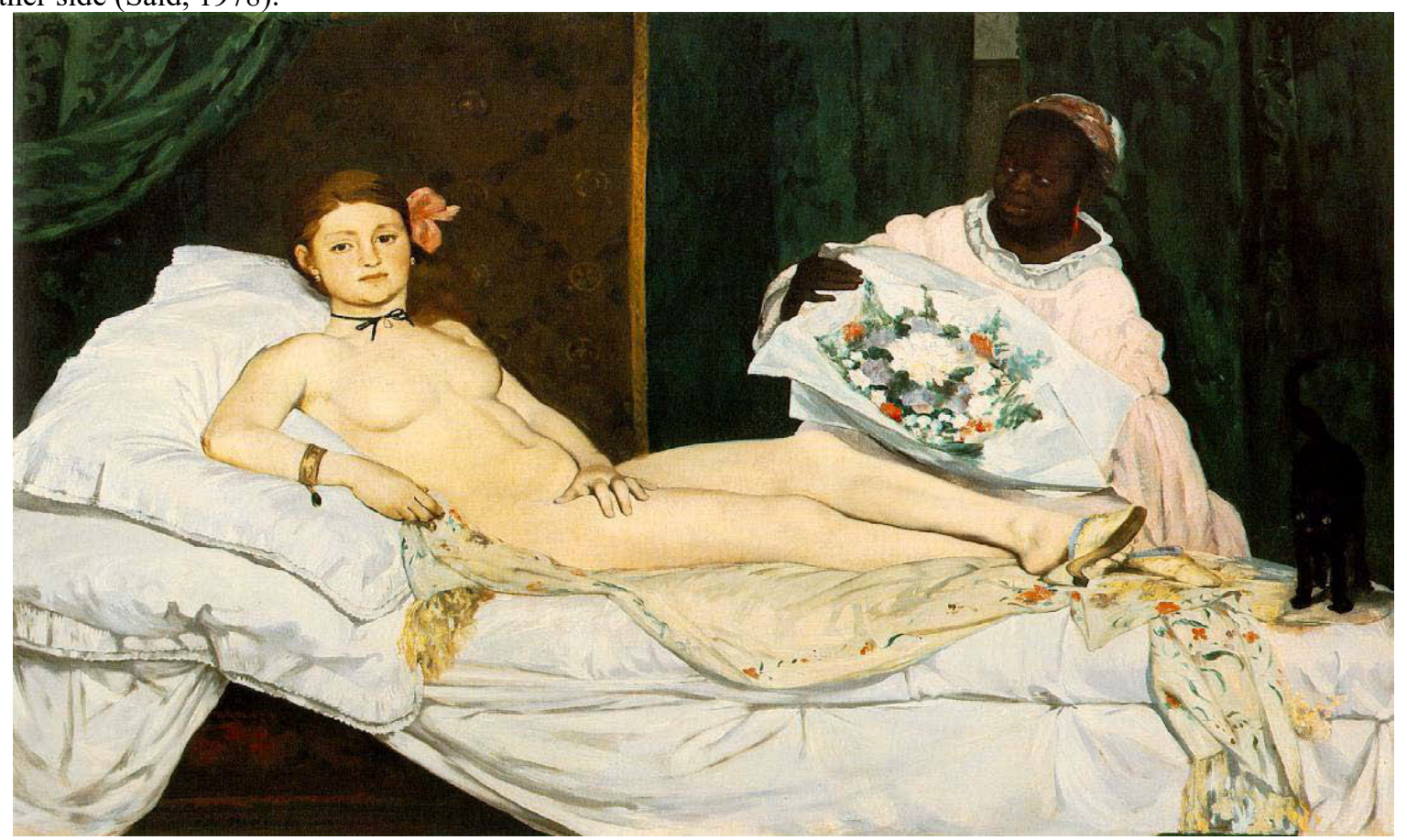

Figur 2: Manet, Olympia, 1863. oil on canvas, Musée d'Orsay, Paris. 
This study critiqued the transformations of the feminist/feminine subject from the voluptuous perceptions to the political objectification through 'de-orientalizing' and 'de-colonizing' the narratives of western modern art towards the realities of contemporary Eastern arts. Orientalist artists represented eastern women as well as eastern social scenes into many paintings in which nude oriental women of Asian, Muslim and African cultural identities resembled into sensuous compositions. They were portrayed according to western sexual aesthetics. In the orientalist paintings, the European qualities of beauty such as fair flesh tones and straight hair appeared on the female models. The western modernism delivered significantly clear clichés of the orient. Therefore, this established western-centric aesthetics and reproduced a form of neoclassical hierarchy in beauty and arts.

The current critique is not trying to label the history of Orientalism, neither is trying to make any general judgments on the orientalist heritage as anti-eastern discourse. Nevertheless, it focused on the fallouts of the orientalists when they misrepresented the different other, where some western politics, poetics, and arts established stereotypical images of the nonwestern societies where men, women, children were represented as opponents and less civilized. In some parts of the western records, the eastern society was perceived as masculine and misogynist towards women and skeptic toward children (Said,1978). The colonial history established colonized subjects and people who needed to be colonized and thus developed and civilized. Orientalism was the cultural reason for colonizing the east, which lacked the western modernity according to the western-centric colonial proposals.

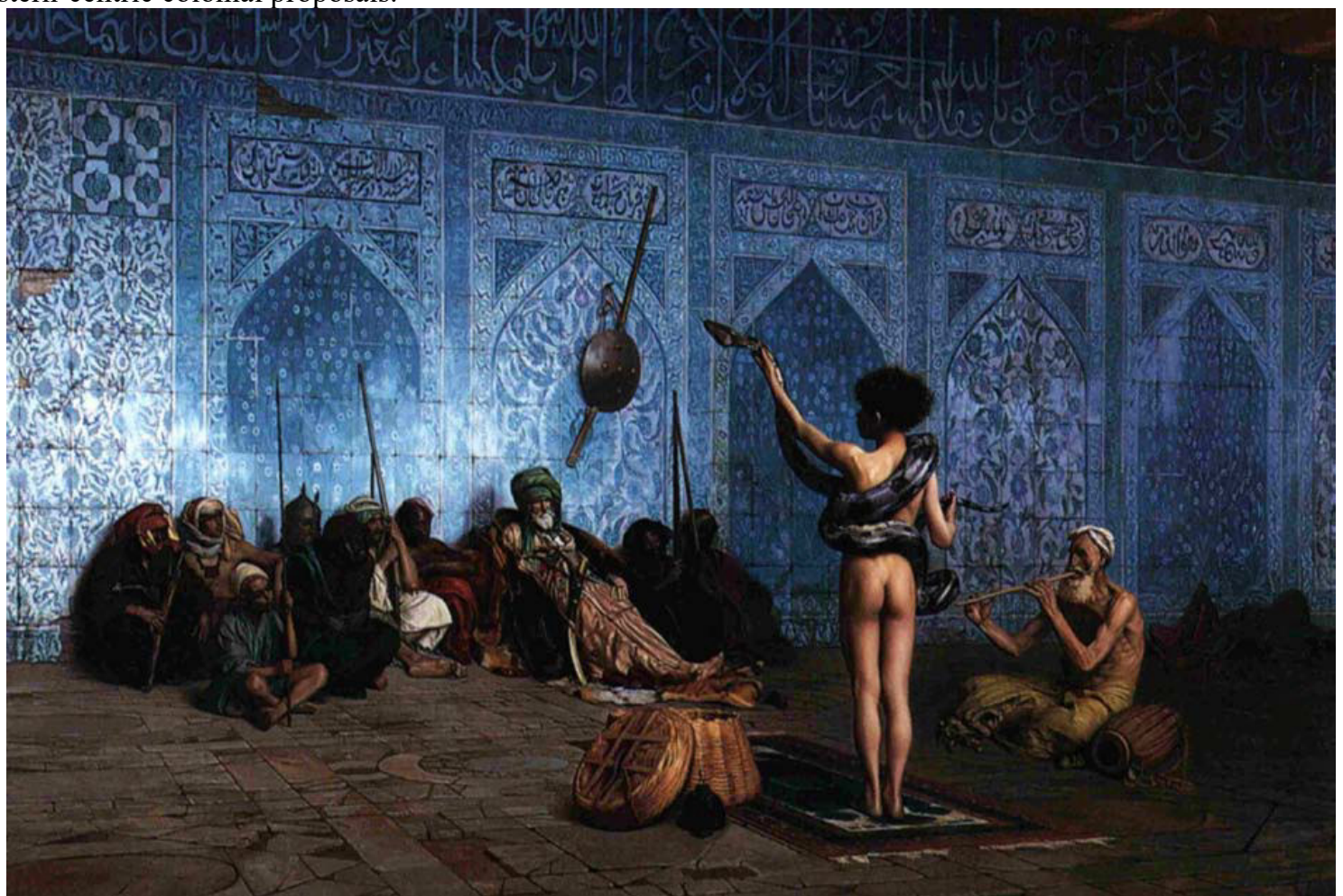

Figure 3: Gerome, the Snake Charmer, 1880. Oil on Canvas, Sterling and Francine Clark Institute, Williamstown, USA.

The orientalist creativity represented the eastern world as an object, a symbol of sexual, commercial and political fantasy and imperialistic dreams through which peoples and geographies were colonized and controlled. The classical metaphor of the un-modern orient and the modern occident was constructed through culturally, politically and socially dialectic discourse of representing submissive and oppressive opponents. This was a parallel reflection between the colonizer and the colonized. The cultural, social and political forms of Orientalism made different narratives through histories and geographies. The geopolitical labeling of the 'Occident' towards the 'Orient' produced social classifications such as 'advanced' and 'backward' practicing cultural and political condescending bureaucracy. Such geopolitical and colonial narratives shaped to some extent the hierarchies of aesthetics practiced all through cultural and artistic research in different subject areas.

The western aesthetics and its interpretations affected the colonial culture where the occidental modernity reproduced the western culture in the colonized geographies. In this context, the critique of Orientalism exposed different transitive layers of western modernism and colonialism. This reinterpretation exposed the aesthetics through a trans-modern framework and critiqued the lack of multicultural negotiations in the western-centric art literature. Since World War II, the context of the anti-colonial criticism reviewed different concepts of the other men, other women, and other immigrants. The philosophy of otherness became a condition of contemporary 
urbanism. The temporalities of the western subject overlapped through an inter-subjective conceptualization with the colonial and postcolonial subject.

The social reality of the East is different from the representations delivered by the orientalists of the 19th century. Those orientalists represented the Eastern autonomous beauty according to their neoclassical aesthetics, which mostly did not realize eastern cultures. This happened when modernist artists and scholars described the oriental culture without even visiting and understanding its dynamics. They did not realize the reality that each culture has its aesthetics, and each culture has a different social reality (Acuna, 2013). Social temporality is the environment where the artist encountered daily experience. This temporality influenced diverse and intersubjective occasions of human creativity. In many cases, the artist reflected social values, which are an integral part of the society's culture.

The hypothetical point of view in this study is that the social dynamics in the eastern communities are the conceptual framework of any potential trans-modern study practiced on visual arts. In the context of eastern social dynamics, this study denoted the significance of investigating and exploring arts through the lens of society rather than the literature of the orientalists. It is the common figure of speech on imagination versus reality when many orientalists did not visit the east at all and did not encounter the real eastern culture. Instead, they imagined it and exaggerated it with false symbolisms. These dynamics interact together to influence creativity into different social levels. They manifest from political interventions, which practice major influence over the local social realities. The socio-politics provoked the artistic landscape involving institutional levels and connecting arts with political layers.

The progressive subject that furthers this hypothetical association of social conceptual framework for this study is the feminist/feminine aesthetics. Women face a variety of dilemmas that exclude them from participating in the social progress of the community; nevertheless, it could be the same problem that has different dimensions according to the country (Wijdan, 2003). In this hypothetical context, the trans-modern obsession of integrating the conventional values into contemporary culture becomes obvious in present society. Globalization influenced communities to follow the latest development in life aspects but in the same time, the question of keeping the inherited values manifested in the course of this development to give indications over the social reality of the current culture. This question of identity through collective versus individual thoughts negotiates the common social and political patterns of the community and challenges its collective or mainstream thoughts (Barakat, 1995).

\section{Recreating Multicultural Aesthetics into Global Arts:}

The dilemma of feminine/feminist art is a diverse contemporary argument, which is constructed of a different point of views. They are the common perception of the women and feminine art, and the way of understanding feminine visuals, and interpreting them into certain codes of cultural knowledge. The structure of this conception in visual arts reproduces into three levels or components, which are form, content, and subject (D'Alleva, 2005). All these levels lead to a subjective interpretation of a feminist/ feminine/ orientalist artwork. On the other hand, Reality stands for the actual meaning of the cultural object represented in the artwork, therefore reality leads to an objective interpretation.

This argument can be applied to the focal point of this study, which is the oriental woman's image in the western art of painting. The art that existed in the modernist era when the west started its colonial waves toward the orient and painting was one tool of its colonialism (Frascina and Harris, 1997). Such argument presented layers of meanings and interpretations exposed by the oriental artist into the subject and the object of the artwork itself emerging together to form the feminine identity which is the context of this study.

In this regards, the phenomenon of global art is an influential tool to reconstruct new forms of multicultural aesthetics. Artists offer in terms of exploring the current social issues by investigating their society within their culture. They convey the image of the real Orient to other people from other regions of the world and interact beyond their local society and become a link between the local and global art, therefore the social reality could be considered as a characteristic tool to aestheticize the local arts from a certain culture, and extend it to the global aesthetics. The relationship between the eastern arts that originate from the orient and their social realities manifest in the environment of global exhibitions while identifying collective philosophies toward assembling different artists from the world and expose them to the global art scene (Eric, 2006).

Social dynamics may not be traditional and create a significant impact on cultural aesthetics. In other words, artists search for new methods and contents for their artworks, rather than keeping themselves prisoners for the anthropological or archeological perspectives. They are transforming the artistic experience from the historical subjects to the contemporary subjects, and associate these transformations with the social realities of oriental societies today. The trend of multicultural aesthetics emerged through locating new artistic intercourses in the international art scenes. The exploration of new styles of visual representations enriched the literature on social realities that appear in contemporary arts. Locating the interaction between the artists' ideas and the global art events themes recognized the similarities and differences in the varieties of the oriental social culture. On the 
other hand, the interaction between the visual research and contemporary art practices link the local social realities with the global themes of the visual culture.

The philosophy of multicultural aesthetics is polycentric, into which, the contributions of all artists from different regions and cultures represent individual aesthetic values of different angles. These aesthetical values whether cultural, religious, or political interact within one global space. This develops our understanding of the contemporary art themes; furthermore, they give more insights into the artistic subjects by exhibiting different artworks. This makes global art a meeting point of diverse similarities and differences. Where each artist expresses art in significant individuality, while this individuality takes influence from the community in different ways and the artist as an individual in his community interacts with various dynamics. The geographical culture would play a significant role in the understanding of the intrinsic aesthetics of artworks, along with any connection of the region itself with other regions or other global events happing on a global scale.

\section{The Conclusion of the Thematic Turn:}

The impact of the regional culture on global aesthetics created different contexts. This study did not try to stereotype them, neither did try to label them, but cast light on their phenomenological reality from various perspectives. Corresponding to the concept of multicultural aesthetics, that defends the need to examine closely and understand the current social temporality on the ground, it draws an edge between the illusion and reality. Imagined arts sometimes establish stereotypical images regarding social or political phenomena, which led to creating illusion instead of representing reality, this confronts social reality with truth, to make one assume whether reality is true and genuine or it is ostensibly a reality because we do believe so (Nanjo, 2008). Themes are part of organizing the social orientation of any art practice, associating particular social/cultural/feminine/political identity that sets the art product somewhere in the context of the global art events. Themes are articulated by selecting evocative signs and styles to distinguish the artworks presented. The function of the theme is significant because it is the context of artworks presented in the biennale or the symposium; the theme would give answers and frameworks and would give viewers a certain order to understand the subjects of the individual artworks.

The concept of practicing culture in the social community to develop the aesthetical systems demands people to believe in their culture and use it to improve their lifestyle. There are practices of values that could change and develop social regards. Art as an aesthetical system produces values, in which we believe; therefore art is a belief system when people construct collective perception to appreciate it. Therefore, aesthetics stands for cultural principles and concepts that make people's experiences better (Nanjo, 2006). People engage with aesthetics and culture through art and art's displaying spaces. On the other hand, the artist expressed spiritual ideas as a part of their cultural identities. The global multiculturalism made it possible to rethink and recreate the hierarchies of aesthetical experience, and to introduce the art audience to new contemporary art participations. In the same context, the dilemma of multiculturalism resembles an individual side of the cultural aesthetics that reflect the personal identity of the artist. It exposes the reality from the artist's point of view, suggesting new approaches to represent reality by avoiding the stereotypical models of aesthetics.

\section{List of references}

Acuna, K. (2013). Osman Hamdi Bey and the Green Mosque: Architectural Imagery in the Construction of an Ottoman Historical Narrative. undergraduate thesis, Department of Art History Binghamton University, State University of New York.

Ali, W. (2003) Clichés of Muslim Women in the West and Their Own World. Diogenes August (vol. 50 no. p.377-87).

Barakat, A. (2009) baring the middle east, canvas magazine.

Barakat, H. (1995). The Arab World, society, culture and state. Berkeley: University of California press.

Balibar, E. (2005) Difference, Otherness, Exclusion, Parallex, vol. II, no. 1, 19-34 (pdf doc.)

Bersson, R. (2003). Responding to Art: form, content, \& context.USA: McGraw- Hill.

Bertens, H. (1995) the idea of the postmodern, Routledge: London \& New York, Broadbeck. (2002). a Cultural Forum: Corporate Cultures in Global

Interaction. Gutersloh.

D'Alleva, A.(2005). Methods \& Theories of Art History. UK: Laurence King Publishing ltd.

D'Alleva, A.(2006). How to Write Art History. UK: Laurence King Publishing ltd.

Danto, A.C. (2001). Philosophizing Art. USA: University of California press.

Eric, Z. (2006). Globalization \& Art Exhibitions. International Association of Art Critics (AICA) \& Zoma Contamporery Art Center Art Criticism \& Curatorial Practices in Marginal Contexts. Addis Ababa.

Elkins, J. (2007). Is Art History Global. London \& New York: Routledge. Routledge.

Fernie, E. (1995). Art History \& its Methods. Oxford: Phaidon.

Frascina, F. \& Harris, J. (1997) Art in Modern Culture: an anthology of critical texts. London: Phaidon. 
Gemtou, E. (2010). Subjectivity in Art History and Art Criticism, Rupcathan, journal on interdisciplinary studies in humanities, volum2, number1.

Gombrich, E.H. (1995). The Story of Art (16 ${ }^{\text {th }}$ Ed). Oxford: Phaidon.

Groat, L. and Wang, D. (2013). Architectural Research Methods ( $2^{\text {nd }}$ ed.). New Jersey, USA: John Wiley \& Sons, Inc.

Harris, J. (2007) Writing Back to Modern Art: after Greenberg, Fried, and Clark. London \& New York: Routledge.

Harris, J. (2011) Globalization and Contemporary Art. Wiley Black-well: UK.

Kleiner, F. S. (2010). Gardner's Art Through the Ages (13 ${ }^{\text {th }}$. Ed.Vol. II). Wadsworth: USA.

Nanjo, F. (2006). Belief: Singapore Biennale 2006 (biennale catalogue, 4 September to 12 November, 2006). Singapore: National Art Council.

Nanjo, F. (2008). Wonder: Singapore Biennale 2008 (biennale catalogue, 11 September to 16 November, 2008). Singapore: National Arts Council.

Nanjo, F. et al. (2012). Arab Express: The latest Art from the Arab World. (exhibition catalogue, 16 June -28 October, 2012). Tokyo: Mori Art Museum.

National Arts Council Singapore (2011), open house : Singapore Biennale 2011 (13 march - 15 may 2011): Dominie Press: Singapore.

Power, C. (2004) women in prehistoric art, in G Barghaus (ed.) New Perspectives on Prehistoric Art. Praeger: Westport, CT/London, pp. 75-103

Preziosi, D. (2009). The Art of Art History. Oxford University press: UK.

Scaltsas, T. (2007). The Ontology of Knowledge and Belief in Republic V, Edinburgh Research Archive: UK.

Sen, Amartya. (2006) Identity and Violence. W.W. Norton \& Company: NY.

Said, E. W. (1978). Orientalism. Vintage Book: NU.

Schwedler, J. \& Gerner, D. (2008) Understanding the Contemporary Middle East. Lynne Rienner: USA.

Sullivan. G (2005), Art Practice as Research: Inquiry in the Visual Arts. Sage Publications: U.S.A.

Walker, J.A. \& Chaplin, S. (1997). Visual Culture: an Introduction. Manchester. 